\title{
Change in smoking habits in a General Practice
}

\author{
SHEILA HANDEL \\ M.R.C.S., L.R.C.P., M.R.C.G.P. \\ General Practioner, London, $W .3$
}

'Cigareets will spoil yer life

Ruin yer health and kill yer baby'

\section{Aims}

IN the summer of 1970 (Handel, 1973) I decided to follow up patients in my general practice and to record any change in their smoking habits, in an attempt to throw some light on the possible effectiveness of a general practitioner in stopping patients smoking.

Between June 1970 and March 1971 one hundred patients were recruited to this study. The patients were smokers with whom I had had no previous discussion of their smoking habits. Patients were not chosen strictly at random but where time and opportunity for discussion arose.

The patients consulted me for the following reasons:

$\begin{array}{lr}\text { Respiratory infections } & 31 \\ \text { Cardiovascular disease } & 4 \\ \text { All other reasons } & 61 \\ \text { Accompanying other patients } & 4\end{array}$

\section{Method}

The discussion took place in ordinary surgery hours in which eight patients an hour are booked. It is therefore unlikely that any discussion took longer than $7 \mathrm{~min}$. The content of the discussion varied according to my assessment of what might influence them and was in appropriate cases related to their illness. An attempt was made to probe the reason why the patient smoked. If this was related to anxiety there was some discussion of this. The health hazards were emphasized and the financial burden. In only five patients was a tranquillizer prescribed. No special literature or questionnaires were used.
Follow-up was continued for 1 year. Each patient was then asked 'How many cigarettes a day do you smoke now?' either when the patient came to surgery or by postal enquiry. No further attempt to discuss the hazards of smoking was made unless initiated by the patient.

The age and sex distribution of patients is shown in Table 1 .

The number of cigarettes smoked at recruitment is shown in Fig. 1. Sixty-one per cent smoked twenty or more cigarettes daily.

TABle 1. Age and sex distribution of 100 patients

\begin{tabular}{ccc}
\hline Age & Male & Female \\
\hline $16-29$ & 11 & 22 \\
$30-49$ & 14 & 18 \\
$50+$ & 20 & 15 \\
Total & 45 & 55 \\
\hline
\end{tabular}

The 100 patients studied.

TABLe 2. Results

\begin{tabular}{lcccc}
\hline & Male & $(\mathrm{N}=45)$ & Female & $(\mathrm{N}=55)$ \\
\hline $\begin{array}{l}\text { Stopped } \\
\begin{array}{l}\text { Reduced by } 50 \% \\
\quad \text { or more }\end{array}\end{array}$ & 17 & $(38 \%)$ & 6 & $(11 \%)$ \\
\begin{tabular}{l} 
Continued \\
\hline
\end{tabular} & 8 & $(18 \%)$ & 12 & $(22 \%)$ \\
\hline
\end{tabular}

\section{Results}

Table 2 shows the numbers who stopped or reduced smoking by $50 \%$ or more.

Table 3 shows the age and sex distribution of those who stopped or reduced.

Table 4 shows that those who reduced or stopped were not confined to the light smokers.

TABLE 3.

\begin{tabular}{lcccccr}
\hline & Age: & \multicolumn{2}{c}{ Under 29 } & \multicolumn{2}{c}{$30-49$} & \multicolumn{2}{c}{ Over 50 } \\
& M(11) & $\mathrm{F}(22)$ & $\mathrm{M}(14)$ & $\mathrm{F}(18)$ & $\mathrm{M}(20)$ & $\mathrm{F}(15)$ \\
\hline $\begin{array}{l}\text { Stopped } \\
\text { smoking }\end{array}$ & 3 & 5 & 6 & 1 & 5 & 0 \\
$\begin{array}{l}\text { Reduced by } \\
50 \% \text { or more }\end{array}$ & 1 & 4 & 3 & 3 & 5 & 5 \\
\hline
\end{tabular}


TABLE 4.

\begin{tabular}{lcccccc}
\hline & & \multicolumn{1}{c}{$\begin{array}{c}\text { Number smoked } \\
20-29\end{array}$} & \multicolumn{2}{c}{30} \\
& M(15) & $\mathrm{F}(24)$ & $\mathrm{M}(14)$ & $\mathrm{F}(25)$ & $\mathrm{M}(16)$ & $\mathrm{F}(6)$ \\
\hline Stopped & 6 & 4 & 4 & 1 & 6 & 1 \\
Reduced by $50^{\circ}$, & 1 & 5 & 3 & 7 & 4 & 1 \\
Continued & 8 & 15 & 7 & 17 & 6 & 4 \\
\hline
\end{tabular}

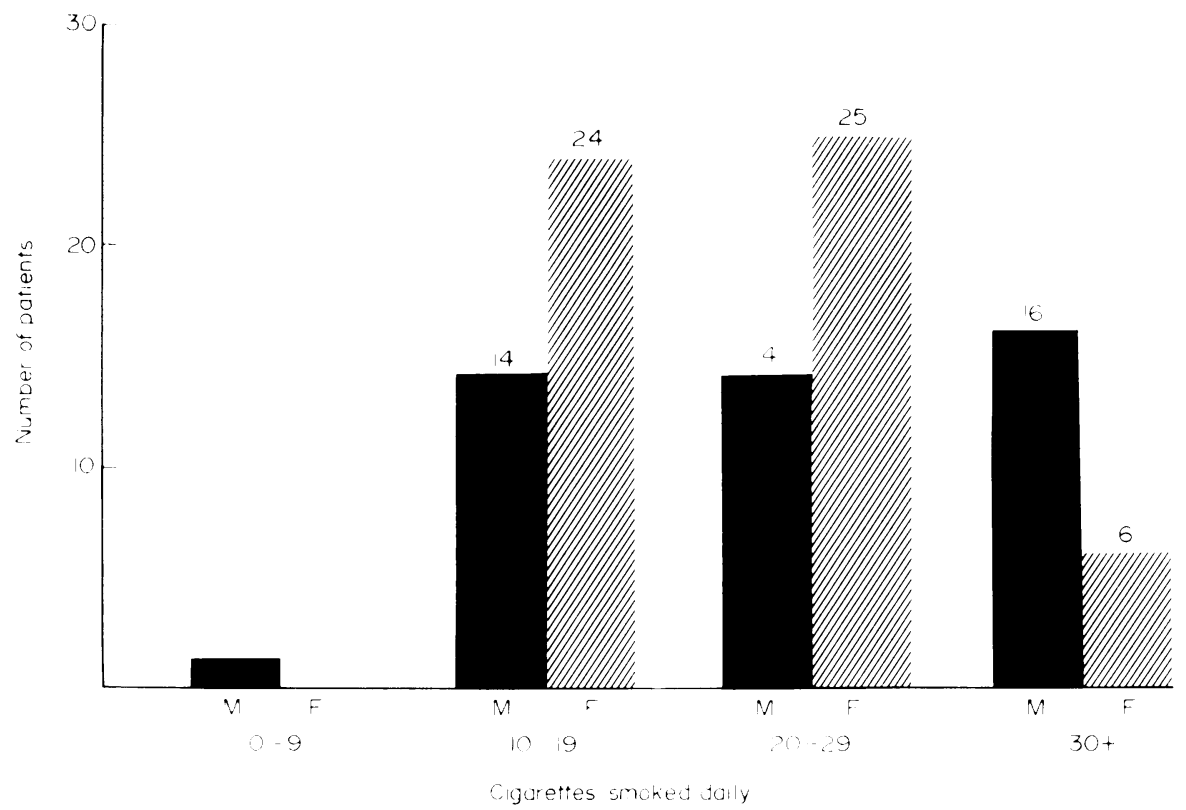

Fig. 1. Dark shading males, stippled females.

\section{Discussion}

In this predominantly working class practice a variety of patients were advised to stop smoking during the course of normal surgery hours, with an appointments system operating. In general, patients were receptive to the ideas put forward by the doctor and none refused to co-operate. One weakness of the study is the lack of random selection of patients included as they were selected as the time and opportunity arose.

Success in stopping patient smoking seemed not clearly related to age. More men stopped smoking than women, the latter seeming more difficult to influence. After 1 year $37 \%$ of the men and $11 \%$ of the women stopped, and $20 \%$ of the men and $21 \%$ of the women reduced by more than half.

\section{Conclusion}

Routine anti-smoking advice in General Practice is worthwhile. It resulted in more than one in three of the men and one in ten of the women stopping smoking.

\section{Acknowledgment}

I wish to acknowledge all the help and encouragement given to me by Dr Keith Ball, F.R.C.P. and by 'Action on Smoking and Health'.

\section{Reference}

HANDEL, S.J. (1973) Journal of the College of General Practitioners, 23, 149. 